Review

\title{
Culture's Influence on the Design and Delivery of the Marketing Mix Elements in Tourism and Hospitality
}

\author{
Erdogan Koc ${ }^{1, * \mathbb{D}}$ and Ahu Yazici Ayyildiz ${ }^{2} \mathbb{D}$ \\ 1 Faculty of Economics, Administrative and Social Sciences, Bahcesehir University, Istanbul 34000, Turkey \\ 2 Faculty of Tourism, Aydin Adnan Menderes University, Kusadasi, Aydin 09460, Turkey; ayazici@adu.edu.tr \\ * Correspondence: erdogankoc@yahoo.com; Tel.: +90-535-835-1954
}

Citation: Koc, E.; Ayyildiz, A.Y.

Culture's Influence on the Design and Delivery of the Marketing Mix

Elements in Tourism and Hospitality.

Sustainability 2021, 13, 11630. https://

doi.org/10.3390/su132111630

Academic Editor: Osman M. Karatepe

Received: 1 October 2021

Accepted: 20 October 2021

Published: 21 October 2021

Publisher's Note: MDPI stays neutral with regard to jurisdictional claims in published maps and institutional affiliations.

Copyright: (c) 2021 by the authors. Licensee MDPI, Basel, Switzerland. This article is an open access article distributed under the terms and conditions of the Creative Commons Attribution (CC BY) license (https:// creativecommons.org/licenses/by/ $4.0 /)$.

\begin{abstract}
This review study presents intercultural research findings relating to elements or aspects of the marketing mix (7Ps) in tourism and hospitality. The study aims to present a comprehensive and compact document on almost all cultural variables/characteristics and all marketing mix elements based on data collected from a wide range of countries supported by several research studies. It is believed that the study will have significant value for researchers, practitioners, and students, both undergraduate and postgraduate, as at present there is no compact and comprehensive document that brings together research findings to establish a cumulative or overall cross-cultural understanding of the design and delivery of the tourism and hospitality marketing mix elements. Currently, studies on culture and tourism and hospitality mainly focus only on one or few cultural variables/dimensions, one or few countries, and one marketing mix element, or various sub-elements of the marketing mix, e.g., sales promotions or advertisements under the promotion element.
\end{abstract}

Keywords: cultural variables; cultural dimensions; Hofstede; tourism; hospitality; marketing mix; 7Ps

\section{Introduction}

The famous quote by Peter Drucker, "Culture eats strategy for breakfast" [1] shows the dominant influence of culture on most business and management activities, including marketing. Culture may have a prevailing influence on people's perceptions, beliefs, attitudes, and behaviors (as customers or service providers) [2-4], as well as on the processes and systems that people establish and manage [1]. Therefore, failing to understand cross-cultural differences and taking the necessary courses of action may have significant implications for the efficiency and effectiveness of business [5]. For instance, overlooking cross-cultural differences between the US and European customers cost Disney over USD 4 billion in 1992 in their Disneyland Paris project [1,6].

Although the perceived cultural distance, or gap, may positively influence tourists' travel attitude [7], as tourists view holidays as opportunities for doing different things than they do in their daily mundane lives [8,9], the perceived cultural distance may generate negative quality of contact and lead to unfavorable emotions, and dissatisfaction with their holidays [10].

A good understanding of cross-cultural differences is particularly important for tourism and hospitality, as the business scene in these industries is becoming increasingly international with the participation of customers from different countries and cultures $[1,11,12]$. Additionally, cross-cultural differences have a significantly greater influence on tourism and hospitality as the level of interaction and social exchange between customers and service providers, and among service providers themselves, tends to be significantly high in tourism and hospitality [13-15]. Due to the intense and continuous nature of social contact and interaction, tourism and hospitality businesses are often referred to as people businesses [1]. 
Certain cultural characteristics are significantly influential in determining a country's or a destination's competitiveness [16]. While individualism, long-term orientation, and indulgence dimensions influence a country or destination's competitiveness positively, factors such as power distance and masculinity were found to be insignificant $[17,18]$. However, this does not mean that the latter two, power distance and masculinity, are not influential in tourism or hospitality. Rather, it means that an increase in these cultural characteristics in a given region or country does not correspond with an increase in the competitiveness of this region or country.

Likewise, as stated above, the performance of a tourism and hospitality business is also very much dependent on the cultural characteristics of its employees and the customers it serves [19]. For instance, the contribution of human resources practices to effective performance increases as the human orientation characteristic of a society increases [19]. Additionally, the contribution of innovation to business performance decrease as the level of power distance increases in a society. Further, the contribution of employee satisfaction to the performance of a tourism and hospitality business is likely to be stronger as the level of in-group collectivism and uncertainty avoidance in a particular society increases [19]. Therefore, it can be stated that a good understanding of the cross-cultural aspects of tourism and hospitality is of paramount importance [20].

In addition to the reasons stated above to justify the study of tourism from a crosscultural perspective, the sheer size of tourism and hospitality need also be taken into account. Tourism is one of the largest industries in the world in terms of both the revenues earned and the employment created [21]. The revenues directly generated in tourism around the world amounted to USD 1.7 trillion in 2019, with the participation of about 1.5 billion international tourists [22]. The direct contribution of travel and tourism to the world GDP is expected to grow by $3.6 \%$ annually to USD 4065 billion by 2029 , representing $3.5 \%$ of the total world GDP.

Moreover, since tourism is interlinked with several other industries, such as transportation, food, beverages, furniture, durables, construction, etc. [1], its actual contribution to the world economy is estimated to be as much as USD 9000 billion [21]. Additionally, as a labor-intensive industry, with about 320 million people working in travel and tourism, direct employment in this tourism represents about $10.5 \%$ of total employment in the world [22].

Another important fact to justify the rationale for this study is that the sheer size and the fast growth of tourism explained above have been achieved with the participation of only $7 \%$ of the world's population in tourism activities [22]. Considering that currently, a rather small proportion of the world population participates in international travel and tourism, there is an important potential for growth for the international tourism and travel industry, with the gradual increases in the proportion of people from various countries taking part in international travel and tourism activities.

However, given the importance of the tourism industry explained above and the strong potential influence of cross-cultural differences on tourism marketing mix elements, studies investigating marketing mix elements in tourism from a cross-cultural perspective have been rather limited, far from providing a complete picture. This is mainly due to the following:

(i) So far, research studies have mainly investigated only one cultural dimension and in some cases only one aspect of one dimension. For instance, the influence of power distance on customer and service provider interaction [23].

(ii) So far, research studies, in general, have investigated only a few countries, mostly one or two, and provided examples relating to these few countries [9].

(iii) So far, research studies have concentrated on only one marketing mix element, e.g., promotion/marketing communications, and in most cases one aspect of one element, the influence of collectivism on attitudes towards monetary and non-monetary sales promotions [24]. 
As countries may have different scores for different variables and each of the variables may have different influences, the above-mentioned studies may be looking at culture's influence on various issues from a rather narrow lens. Therefore, based on the above explanations, the need for a comprehensive yet succinct study to provide a framework on cross-cultural marketing aspects of tourism and hospitality is obvious. Such a comprehensive study would be of use not only for the practitioners (i.e., employees and managers working in tourism and hospitality establishments) but also for trainers, educators, and researchers focusing on almost any aspect of tourism and hospitality.

\section{Framework for the Study}

Against the above backdrop, this study explains and discusses the influence of culture on customers and the marketing mix elements (7Ps) based on the research findings published in reputable international journals and books. In doing this, the study particularly concentrates on the top ten outbound tourism countries (including Hong Kong, a special administrative region of the People's Republic of China) that send the highest numbers of tourists abroad and the top ten countries/regions whose citizens spend the highest amount of money in international tourism activities (See Table 1). However, as the above countries/regions represent a spectrum of countries with high, medium, and low scores in terms of various cultural variables, it is believed that the findings presented here may represent a greater majority of countries in the world and almost all tourism and hospitality activities.

As seen in Table 1, there are 12 countries in the top ten outbound tourism list, and although some countries may not be among the top ten in terms of tourist numbers, they may be among the top tourism spenders and vice versa. As these countries represent almost $60 \%$ of all world tourist numbers and more than $34 \%$ of all world tourism spending, presenting a comprehensive study on the implications of intercultural characteristics on the marketing mix elements in tourism and hospitality may have significant value both for researchers and practitioners.

Table 1. Top Tourist Sending Countries * (based UNWTO Data-2019) [21].

\begin{tabular}{|c|c|c|c|c|c|c|c|}
\hline \multicolumn{4}{|c|}{ Numbers of International/Outbound Departures } & \multicolumn{4}{|c|}{ Top International/Outbound Tourism Spending } \\
\hline Ranking & Country & $\begin{array}{l}\text { Tourist } \\
\text { Numbers }\end{array}$ & $\begin{array}{c}\% \text { (of World } \\
\text { Tourism Spending) }\end{array}$ & Ranking & Country & $\begin{array}{c}\text { Tourist } \\
\text { Spending } \\
\text { (Billions of } \$ \text { ) }\end{array}$ & $\begin{array}{c}\text { \% (of World } \\
\text { Tourism } \\
\text { Spending) }\end{array}$ \\
\hline 1 & United States & $157,873,000$ & 10.52 & 1 & United States & 182.366 & 10.73 \\
\hline 2 & China & $154,632,000$ & 10.31 & 2 & Germany & 99.865 & 5.87 \\
\hline 3 & Germany & $108,542,000$ & 7.24 & 3 & France & 60.726 & 3.57 \\
\hline 4 & Hong Kong * & $94,715,000$ & 6.31 & 4 & United Kingdom & 41.458 & 2.44 \\
\hline 5 & United Kingdom & $93,086,000$ & 6.21 & 5 & Australia & 41.43 & 2.44 \\
\hline 6 & Mexico & $82,752,000$ & 5.52 & 6 & Canada & 41.247 & 2.43 \\
\hline 7 & Italy & $62,207,000$ & 4.15 & 7 & Russian Federation & 40.611 & 2.39 \\
\hline 8 & Poland & $50,600,000$ & 3.37 & 8 & Italy & 37.908 & 2.23 \\
\hline 9 & France & $49,276,000$ & 3.29 & 9 & South Korea & 34.844 & 2.05 \\
\hline \multirow[t]{3}{*}{10} & $\begin{array}{l}\text { Russian } \\
\text { Federation }\end{array}$ & $45,330,000$ & 3.02 & 10 & $\begin{array}{l}\text { United Arab } \\
\text { Emirates }\end{array}$ & 33.372 & 1.96 \\
\hline & Total & $899,013,000$ & 59.93 & & Total & 580.455 & 34.14 \\
\hline & $\begin{array}{c}\text { Total World } \\
\text { Tourist Numbers }\end{array}$ & $1500,000,000$ & 100.00 & & $\begin{array}{c}\text { Total World } \\
\text { Tourism Revenues }\end{array}$ & 1700 & 100.00 \\
\hline
\end{tabular}

* Special An administrative region of the People's Republic of China.

\section{Cultural Characteristics}

Various paradigms, dimensions, and variables have been developed by researchers to explain and understand cross-cultural differences and similarities. This study concentrates mainly on cultural variables/dimensions developed by Hall [24] (high-and low context cul- 
tures) and Hofstede [25] (i) power distance, (ii) individualism-collectivism, (iii) uncertainty avoidance, (iv) indulgence-restraint, (v) masculinity-femininity, and (vi) time orientation) as they are the most frequently used cultural variables/dimensions [15,26-28].

For instance, the research by [29] explored the frequency of the use of the intercultural paradigms in top international business and management journals, finding that more than $75 \%$ of studies were based on the two commonly used paradigms [25,26]. However, from time to time, references to other cultural characteristics such as performance orientation and humane orientation will also be made. Table 2 demonstrates the cultural characteristics scores of the above top ten outbound tourism countries/regions [26], based on the most frequently used paradigm. As the explanations of the cross-cultural variables would make the study unnecessarily lengthy, this study provides only the implications of these cultural variables on tourism and hospitality marketing mix elements (product, price, place, promotion, people, process, and physical evidence) based on empirical research findings without explaining what they are and what they involve. It needs to be pointed out here that as the consequences of the COVID-19 pandemic are not static and change over time, and lengthy discussions and examples provided in the study may prove over time to be only speculations. The consequences of the COVID-19 pandemic were not included in this study.

Table 2. Cultural Characteristics of East and South Asian Counties.

\begin{tabular}{|c|c|c|c|c|c|c|}
\hline Countries & $\begin{array}{c}\text { Power } \\
\text { Distance } \\
\text { (PDI) }\end{array}$ & $\begin{array}{l}\text { Individualism } \\
\text { (IDV) }\end{array}$ & $\begin{array}{c}\text { Masculinity } \\
\text { (MAS) }\end{array}$ & $\begin{array}{c}\text { Uncertainty } \\
\text { Avoidance } \\
\text { (UAI) }\end{array}$ & $\begin{array}{l}\text { Long-Term } \\
\text { Orientation } \\
\text { (LTO) }\end{array}$ & $\begin{array}{c}\text { Indulgence } \\
\text { (IND) }\end{array}$ \\
\hline Australia & 38 & 90 & 61 & 50 & 21 & 71 \\
\hline Canada & 39 & 80 & 52 & 78 & 36 & 68 \\
\hline China & 80 & 20 & 66 & 30 & 87 & 24 \\
\hline France & 68 & 71 & 43 & 86 & 63 & 48 \\
\hline Germany & 35 & 67 & 66 & 65 & 83 & 40 \\
\hline Italy & 50 & 76 & 70 & 75 & 61 & 30 \\
\hline Hong Kong * & 68 & 25 & 57 & 29 & 61 & 17 \\
\hline Mexico & 81 & 30 & 69 & 82 & 24 & 97 \\
\hline Poland & 68 & 60 & 64 & 93 & 38 & 29 \\
\hline Russian Federation & 93 & 39 & 36 & 95 & 81 & 20 \\
\hline South Korea & 60 & 18 & 39 & 85 & 100 & 29 \\
\hline United Arab Emirates & 90 & 25 & 50 & 80 & $\mathrm{~N} / \mathrm{A}$ & $\mathrm{N} / \mathrm{A}$ \\
\hline United Kingdom & 35 & 89 & 66 & 35 & 51 & 69 \\
\hline United States & 40 & 91 & 62 & 46 & 26 & 68 \\
\hline
\end{tabular}

(Source: Hofstede, G. (2021), Cultural Dimensions [online]. Available online: https:/ /www.hofstede-insights.com/product/comparecountries/ (accessed on 15 March 2021), Used with permission). * Special Administrative Region of the People's Republic of China.

\section{Implications of Cross-Cultural Differences on the Marketing of Tourism and Hospitality}

This section explains and discusses how cross-cultural characteristics may influence the design and the delivery of the marketing mix elements, i.e., product, price, place, promotion, people, process, and physical evidence.

\subsection{Product}

Product decisions involve decisions such as the design and delivery of package holidays, menus, and all the food items and beverages served in a restaurant. It is wellknown that tourism and hospitality customers engage in activities and the types of tourism and hospitality products they prefer, which tend to be in congruence with their self-image, largely shaped by their cultural characteristics [30]. In turn, as established in a study [31] with participants from 35 countries, including all the countries in Tables 1 and 2, this self-image of people, which determines their tourism and hospitality product and activity choices, is significantly influenced by their cultural characteristics [31]. 
Likewise, a study with the participation of tourism and hospitality customers from the UK, Germany, Brazil, Taiwan, and Japan showed that tourism and hospitality customers behaved in line with their culture-shaped mental programs [32]. For instance, research shows that [33] the choice of medical tourism products and destinations is to large extent shaped by their culture.

In another study [34] with tourists from 20 countries (including the US, the UK, Canada, Germany, France, Italy, Australia, and South Korea above in Tables 1 and 2) visiting Hong Kong, it was found that masculinity and power distance had a positive influence on the amount of money that customers spent on shopping during their visits. This means that destinations and tourism establishments targeting tourism and hospitality customers from cultures with high power distance and high masculinity pay special attention to shopping amenities. Additionally, while tourists visiting a destination who come from countries with high cultural distance tend to shop more for souvenirs or gifts [35], tourists who come from similar cultures (e.g., Canadian tourists visiting the US) may shop for more daily use items such as groceries, foods, and clothes [36].

Additionally, collectivist customers (e.g., customers from China, Hong Kong, South Korea Mexico, and the United Arab Emirates) tend to buy and give more gifts, have larger gift budgets, and have more occasions to exchange gifts, compared with individualistic customers (e.g., customers from Australia, Canada, the UK, and the US) [37]. Collectivists tend to feel more pressure to reciprocate gifts [38]. Additionally, customers from long-termoriented cultures may exchange more gifts and have more occasions for gift-giving and taking as people from these cultures value long-term relationships [1].

Power distance is usually considered as one the most influential cultural dimensions influencing tourists' holiday product and destination choice decisions [39]. Customers from cultures with high power distance tend to depend more heavily on the quality and brand image of the business when making their holiday decisions.

Likewise, research showed that customers from cultures with high power difference place a much greater emphasis on the tangible elements regarding the tourism and hospitality products, as the grandeur of the tangible objects conveys messages regarding people's statuses in the hierarchy $[40,41]$. The grandeur of tangible objects may signal high status, luxury, exclusivity, and elitism, which customers from cultures with high power difference tend to value.

Cultural differences may also influence food consumption and socializing in tourism and hospitality activities. For instance, customers from high-context cultures tend to have more sensory involvement in dining, entertainment, and socializing [42]. This means that when targeting tourism and hospitality products from high-context cultures, their higher level of sensory involvement with dining, entertainment, and socializing needs to be taken into account. Customers from Hong Kong are more likely to prefer hedonic services than UK customers due to the high level of power distance in the UK [43].

As another cultural characteristic, uncertainty avoidance also influences the tourism and hospitality product choices of customers. Customers with a high level of uncertainty avoidance tend to prefer all-inclusive package holidays to customers who have a low level of uncertainty avoidance [1,44]. According to research, risk-taking correlates with sensation seeking, variety seeking, and engagement in risky activities such as participating in extreme sports and adventure holidays [45-47]. Tourists from cultures with a low level of uncertainty avoidance are more likely to take risks, seek thrills, and engage in high-energy and outdoor activities such as hiking and mountaineering and therefore, prefer more active and spontaneous vacations [48].

On the other contrary, tourists who are from cultures with high uncertainty avoidance tend to choose slow-paced and indoor based activities (e.g., participating in staged events, shopping, visiting friends, and relatives) [48], stay at their own holiday homes, or take part in general interest tourism (e.g., sun, sand, and sea tourism) [1]. The Japanese (a culture with high uncertainty avoidance) tend to be keen to own hotels abroad (e.g., in Australia) 
mainly because many Japanese believe that only the Japanese can fully meet the needs of other Japanese [49].

As opposed to cultures with low uncertainty avoidance such as Germany, the UK, and the US, tourists from Japan often resort to uncertainty-reducing behaviors such as participating in package holidays, traveling with groups, making rigid holiday plans, participating in "staged" events, preferring their own cuisine, visiting fewer destinations, and staying shorter periods at each destination [1,50,51]. The Japanese tend to be keen to own hotels mainly because many Japanese believe that only the Japanese can fully meet the needs of other Japanese [44,50-52]. However, it needs to be pointed out that participating in package holidays as groups may not be seen as a risk-reduction strategy nowadays, as being physically close to people may raise health concerns among people after the COVID-19 pandemic [1].

Package holidays, while offering an environment for collective social interaction, also minimize risks by providing a standardized tourism experience [52]. Again, while the social interaction aspect of package holidays may satisfy the needs of collectivistic customers, the provision of standardized tourism experience and minimizing risk elements may satisfy the needs of customers from uncertainty avoidance cultures. However, customers from cultures with high uncertainty avoidance can also be highly competitive and may wish to take part in tourism and hospitality activities that provide novelty and adventure [53].

From an individualism-collectivism perspective, research shows that $[54,55]$ tourism and hospitality customers from individualistic cultures (e.g., the US and Germany) tend to prefer customized products and services. The restaurant customers from the USA tend to enjoy the service more when the waiters made more frequent check-backs. This may be due to the fact that frequent check-backs may allow opportunities for the US customers to express themselves for customizing the service according to their preference [53].

As future-oriented customers are more likely to focus on cost-benefit analyses regarding the expected outcomes of future events, they may have a higher level of orientation to seek knowledge before they make their purchase decisions [56] and may prefer tourism and hospitality activities with opportunities for personal development [57]. While countries such as Germany, the UK, Australia, and the United States can be classified as relatively future-oriented, countries such as China, Italy, Russian Federation, France, and Poland can be classified as countries with a low level of future orientation. According to research, future-oriented tourists, especially the senior ones, tend to prefer holidays that offer opportunities for personal development, learning, and discovering new things [58,59]. Customers from future-oriented cultures may be more likely to be aware that tourism and travel may enhance healthy aging, prevent certain illnesses, and help maintain both mental and physical health $[59,60]$. Research studies $[59,60]$ show that tourists from future-oriented cultures are more likely to take part in travel and tourism activities with motives of self-fulfillment and knowledge enhancement. On the other hand, past-oriented tourists tend to be more involved in sensation-seeking, hedonistic, and indulgent holidays involving activities such as spending time at a beach resort or participating in cruise holidays $[1,57,59,61]$. It was found that past-oriented women were more interested in activities linked to their childhood memories, whilst present-oriented women preferred hedonic pursuits, and future-oriented women were more interested in personal development activities [57].

The masculinity and femininity paradigm also has a significant influence on the tourism and hospitality product preferences of customers. For instance, while tourists from masculine countries such as Germany, Italy, and the USA are more interested in dynamic and active tourist products or activities, compared with tourists from feminine countries such as South Korea and Spain, who tend to prefer more passive, static softer, gentler, people- and culture-oriented holidays involving visiting friends and relatives, shopping, attending cultural and arts festivals, going to the opera, ballet, theatre, etc. [62].

In another study [63] on masculinity, it was demonstrated that while franchised restaurants would be more suitable for customers from masculine countries such as China, non-franchised restaurants would be more suitable for customers from feminine cultures 
such as South Korea. Researchers [64] argue that franchised restaurants tend to have set personal/individual responsibilities of each staff member, and they tend to focus on time and achievement of the tasks, which may overlap with masculine characteristics. On the other hand, non-franchised restaurants may tend to have shared responsibilities (e.g., among the wait staff), and they may focus more on being empathetic and responsive, which may better overlap with feminine characteristics.

According to research [50], Japanese people are more likely to leave their travel arrangements to travel agencies since they are from a culture of high uncertainty avoidance. However, this consequence may be related to a lack of involvement, due to the low level of indulgence (i.e., a high level of restraint) in the Japanese culture. Although the above study [50] was based on the uncertainty avoidance paradigm and the promotion element, the findings of the study could be interpreted from the perspectives of the indulgence and restraint paradigm and the product element.

\subsection{Price}

The price element is relatively more important as it directly determines how many units of a product or service will be sold, if any. Pricing is especially important for tourism and hospitality businesses as tourism and hospitality products involve relatively high amounts of funds for products/services that cannot be tested before purchase and consumption. Hence, no matter what the cultural characteristics of the customers are, pricing decisions always have important implications for tourism and hospitality businesses.

A study [39] with tourists from North America, the UK, and the North European countries visiting Portugal found that people from collectivistic countries had a higher likelihood to be more price-conscious and made their purchase decisions based on brand, prices, and the number of alternatives. On the other hand, tourists from individualistic countries had their own criteria. Moreover, as opposed to individualistic and low-context (most of the west European countries and people from North America) customers, customers from collectivistic and high-context cultures depended more on the price-quality relationship when making their tourism and hospitality purchasing decisions [64].

Likewise, customers from high-power distance cultures tend to use price to evaluate the quality [65], though they may largely choose to refrain from bargain hunting as bargain haunting may signal lower status [1]. In line with the above, tourists from cultures with high power difference also have a greater propensity to believe that high prices reflect a higher level of quality [41]. A rise in the prices appears to increase not only tourists' expectations but also their level of happiness before consumption [41].

Just like tourists from cultures with high power difference, tourists from cultures with high uncertainty avoidance also tend to be content with the display of inequality in prices [66,67]. As customers from cultures with high uncertainty avoidance have a pressing need for order and structure, they tend to associate the level of price with the level of potential risk. While exposure to a hotel's pricing policy appears to have a positive influence on South Korean tourists' level of satisfaction, tourists from the US, with a low level of uncertainty avoidance, tend to remain largely unaffected by this exposure [65].

Additionally, customers from countries with long-term orientation (e.g., from South Korea and China) are less likely to make impulsive purchases, as they tend to make more careful plans, evaluate the alternatives, and take future concerns more into account when they make purchasing decisions [68,69]. South Korean restaurant customers are also more likely to be able to delay their gratification, are more frugal, and are less likely to become unable to pay their credit card bills [69]. On the other hand, Chinese tourists tend to attach more weight to price-value relationships and have more tangible expectations (e.g., amenities and the facilities at a hotel) in relation to the price they paid $[70,71]$. Based on the fact that long-term-oriented tourists are not impulsive, are more frugal, and are more likely to plan ahead for the future, they may be less likely to pay attention to yield management pricing strategies [1]. 


\subsection{Place}

While the place element for tangible products refers to logistics, distribution channels, store layouts, etc., in services, the place element can refer to anything that may relate to making products/services available for customers' purchase, use, or consumption. Hence, although the decisions relating to the Internet webpages of tourism and hospitality business may be considered under the promotion (marketing communication) element, they may also relate to place strategies.

As stated above, Japanese tourists who have a low-level involvement tend to leave their holiday arrangements to travel agencies due to their high level of uncertainty avoidance [50] and low level of indulgence [1]. A major study [30] with 46,000 tourists visiting the US from a wide variety of countries showed that people from cultures with high uncertainty avoidance preferred to use personal information sources such as travel agencies, tour operators, friends, and relatives when making their purchase decisions.

Travel agencies tend to have a strong influence on Japanese people's medical tourism decisions [55]. Tourists from cultures with high uncertainty avoidance such as France and Belgium also tend to use low-risk information sources (travel agencies), while the tourists from the UK, who have a low level of uncertainty avoidance, do not tend to associate online information with risk [72].

Just like the link explained above about uncertainty avoidance and the use of online information sources, researchers also found a relationship between uncertainty avoidance and online purchasing $[67,73,74]$. It appears that the association of lower levels of risk with travel agencies was due to the availability of personal interaction and control offered by the travel agencies [73,74]. Nevertheless, with the increase in the numbers of dishonest service providers, tourists, even from cultures with high uncertainty avoidance such as China, tourists have begun to switch from brick-and-mortar travel agencies to online travel agencies [75].

\subsection{Promotion}

The promotion element consists of the design and delivery of all marketing communications and the use of tools such as advertisements, public relations, sales promotions, and personal selling [1]. In addition to the studies explained above relating to the use of information sources by tourism and hospitality customers from cultures with different cultural characteristics, there are several other studies relating to the influence of culture on promotion. For instance, research shows that tourists from long-term-oriented cultures are more likely to use multiple information sources when making their decisions [39]. In terms of the use of information sources, French tourists appeared to have a higher tendency to use proprietary communication channels such as promotional materials (brochures) of hotels or airlines as their primary source of information, whilst German tourists had a higher tendency to use third-party communication channels such as independent travel agencies [76].

Another study compared McDonald's advertisements in high-context countries such as Japan, S. Korea, China, Hong Kong, Pakistan with low-context countries such as Denmark, Germany, Norway, Finland, the USA [77]. The results of the study demonstrated that advertisements in high-context countries contained more detailed and advanced designs, including various images and animations, while advertisements in low-context countries had less animation and more stagnant images, with more detailed information and focused more on verbal information and linear processes [77]. In a similar study [78] it was found that while advertisements from low-context cultures are more likely to be direct and informative, advertisements from low-context cultures are less directly informative. This is because in high-context cultures, information and meaning tend to be implied rather than stated. Additionally, a comparison of Dutch customers (low-context) with French and Spanish customers (a relatively high-context culture) showed that the former had a less liking for complexity in the advertisements [79]. 
Later, a study [80] comparing high-context Belgian customers with low-context Dutch customers discovered that customers from the Netherlands had a lower liking for visual metaphors and found the visual metaphors more complex than the customers from Belgium. This study [80] is in line with a later study [81] that demonstrated that as opposed to lowcontext customers, customers from high-context cultures can draw more implicit meanings from the messages they had been exposed to.

As mentioned above under the product element, the grandeur of the tangible objects conveyed the messages of status and elitism. Additionally, a comparative study of hotel advertisements with Asian and European customers such as the British, Chinese, Malaysian, etc. found that expensive symbols were more preferred by customers from cultures with high power difference as these symbols satisfied these customers' status, prestige influence power, wealth, and elitism needs [41].

Earlier studies $[82,83]$ identified the relevancy of certain advertising appeals for people with different cultural characteristics. For instance, appeals such as safety, tamed, and durable were positively associated with high levels of uncertainty avoidance. Research also showed that while people from masculine cultures perceived advertisements with appeals of effective, convenient, and productivity positively, people from feminine cultures perceived advertisements with natural, frail, and modest appeals more positively [83]. Furthermore, it was found that customers from individualistic countries perceived appeals to independence and distinctiveness positively, while they perceived the appeals to affiliation, family, and community negatively.

A comparative study of Chinese (high power distance) and the US (low power distance) advertisements found that the themes of ornamentation, status, and endearment were more common in Chinese advertisements [84]. In s a similar study [85] in India, a culture with high power difference, it was found that the themes of humility, nurturance, and plainness were negatively correlated with high power distance, while the themes of ornamentation, vanity, endearment, and status were positively correlated with high power distance. Research on time orientation as a cultural variable showed that appeals to health and nutrition were more important for customers from long-term oriented cultures such as the Chinese than those from the short-term oriented North Americans [84,86,87].

Additionally, research on humane and performance-oriented cultures proved that the themes of altruism, benevolence, kindness, love, generosity, affiliation, belongingness, personal, and family relationships in advertisements caused customers from humane cultures to evaluate an advertisement more positively [88]. On the other hand, themes of achievement, urgency, results, and control caused customers both from high- and low-performance-oriented cultures to evaluate an advertisement more positively [88]. Furthermore, the research uncovered that customers from high-performance cultures expected stronger cues to evaluate the advertisement as performance-oriented. On the other hand, weaker-performance-orientation cues in advertisements were sufficient for customers from low-performance-oriented cultures to perceive the advertisement as performanceoriented [88].

Continuing with the time orientation variable, a study [89] that compared the UK, Saudi Arabia, Thailand, and Chile showed that customers with a high level of past orientation had a higher level of a tendency to avoid advertisements. Both present- and future-oriented customers were more positive towards advertisements, though for different reasons. While present-oriented customers were in general positive towards advertisements due to their hedonistic drives, future-oriented customers were in general positive towards advertisements as they thought that the exposure to advertisements may help them learn, which in turn may be useful in solving daily problems they may encounter [88]. Customers from cultures with low power distance tend to place greater importance on the hedonic aspects of consumption than the customers who are from cultures with high power distance $[90,91]$.

As opposed to cultures with high power difference, elements of humour were more commonly found in cultures with low power distance, as they were comfortable parodying 
themselves [92]. Similarly, while smiling in indulgence cultures can be perceived as a norm, in restraint cultures, it may cause suspicion [26]. When McDonald's Moscow was first opened in 1992, the service staff were asked to smile. However, the smiles of the service staff were encountered with suspicion, as the Russians (restraint culture) did not smile at strangers [93]. Similar to the above study on power distance, another study found that the Chinese websites contained a relatively low proportion of people laughing, as the majority tended to have people with serious-looking faces [94]. Research also found that Japanese advertisements had more fear and rules/formality cues due to their restraint, high level of uncertainty avoidance, and power-distance orientations [95]. Although Chinese culture can be classified as a restraint culture, the happiness levels of a destination country were positively and significantly associated with Chinese tourist arrivals in that country [96].

In parallel with the above discussion, researchers found that nudity and sexuality content in marketing communications messages were perceived negatively in masculine cultures as they had stronger taboos relating to sex [97]. This finding may relate to restraint cultures as well. As mentioned above, restraint cultures tend to have strict social norms and encourage the control of hedonistic gratification. These cultures tend to discourage pleasure, enjoyment, spending consumption, sexual gratification, and general merriment [1]

In order to explore the use of information sources used in decision-making, researchers compared Asian restaurant customers with high uncertainty avoidance and North American restaurant customers with low uncertainty avoidance in South Korea [98]. They found that in choosing local South Korean restaurants, customers from countries with low uncertainty avoidance tended to depend more on actual knowledge of the relevant attributes, while customers from countries with high uncertainty avoidance tended to depend more on experience as a risk reduction strategy [98].

Research regarding intercultural differences towards sales promotions found that individualistic customers with short-term orientation tended to react positively to heavy price discounting, while collectivistic customers with long-term orientation were not pleased with heavy price discounts $[99,100]$. Similarly, while customers from masculine cultures are more likely to be positive about monetary-based sales promotions, customers from feminine cultures are more likely to be positive about non-monetary sales promotions [24]. Additionally, sales promotions with female identities, such as coupon collection, did not attract men, especially men with more masculine characteristics [24].

Intercultural differences also influence public relations activities as one of the subelements of promotion. A longitudinal study [101] on corporate social responsibility activities of hotels showed that managers in masculine cultures are less likely to be interested in corporate social responsibility activities, due to their tendency to focus on material gains and economic success. Similar findings were obtained in terms of the individualist characteristics as well. For instance, tourists from Poland, with a relatively individualistic culture, tended to have a low level of interest in the environment [102].

\subsection{People}

People as a marketing mix element comprise all of the human resources involved in the production and delivery of tourism and hospitality products, as well as the beliefs, attitudes, and behaviors these people hold towards customers, their organizations, counterparts, subordinates, and superiors. As stated above, while certain cultural characteristics of the service providers had a positive influence on the efficiency, effectiveness, and competitiveness of the service providers, some others had a negative influence $[16,19]$. For instance, hospitality employees from cultures with low power distance tend to concentrate on the intrinsic factors (achievement, recognition, the work itself, responsibility, advancement, and growth) of motivation [103]. On the other hand, the hospitality employees from cultures with a high power difference concentrated on the extrinsic factors (achievement, recognition, the company policy, relationships with supervisors, working conditions, relationships with peers and subordinates, salary and benefits, and job security) [103]. Additionally, tourism and hospitality employees from cultures with a high power difference 
(e.g., Turkey), as opposed to cultures with a low power distance (e.g., the UK) are more likely to use indirect communication when communicating problems, failures, and crises to their superiors, which results in delays in tackling and rectifying problems and failures, together with maintaining service quality systems [23].

As stated above, due to the continuous and frequent interactions between the service staff and the customers, tourism and hospitality businesses are often referred to as people businesses. Culture appears to be very influential, especially for service interactions [1]. It was stated above that Disneyland Paris incurred major losses, as Disney management overlooked several intercultural differences. The intercultural differences overlooked by the Disney management were mainly related to the people element of the marketing mix [6]. A comparative study of hotel employees in Turkey and the UK showed that Turkish hospitality employees lacked empowerment and used indirect and mitigated speech to communicate service failures/crises to their superiors [1].

Similarly, a study that compared the South Korean (collectivistic) and the US (individualistic) hotel employees found that hospitality employees in collectivistic cultures tended to be uncomfortable with empowerment [1]. Empowerment may have serious implications for tourism and hospitality businesses in terms of reliability and responsiveness dimensions of service quality and for the whole service recovery process $[1,104]$.

As argued above, service employees from restraint cultures may not provide a highquality of service in the tourism and hospitality business as they may find it difficult to internalize the concepts of fun, leisure, and pleasure [1]. In general, while people from indulgence cultures tend to allow hedonistic behaviour and support enjoyment, fun, pleasure, and merriment, restraint cultures appear to have rigid social norms and restrict hedonistic gratifications [26]. US tourists (indulgence culture) tend to be more fun-seeking and less comfortable in crowded atmospheres compared with the Chinese (restraint culture) tourists [105].

Similar to the idea behind the low number of complaints made by customers from collectivistic and human cultures, in cultures with high uncertainty avoidance, employee turnover tends to be low [26], not necessarily due to the fact that the employees are satisfied with their jobs. Employees may stay in their present jobs due to the high level of risk aversion, even though they may be highly dissatisfied with their jobs [1]. In Serbia, a culture with high uncertainty avoidance and high power distance, hospitality employees appeared to obey company rules and place greater emphasis on employment stability, though they experienced significantly high levels of dissatisfaction and stress in their jobs [106].

\subsection{Process}

The process element in tourism and hospitality marketing may comprise various processes such as reservation, booking, payment, check-in, check-out, etc. [1]. As $67 \%$ of all customer switching is due to interaction and exchange failures, and only $14 \%$ of them are attributable to product failures [107], the efficiency and effectiveness of processes become obvious. The service recovery paradox suggests that when a service failure is recovered, a customer's level of satisfaction can be higher than the stage before $s /$ he encountered the service failure [15]. An investigation of the service recovery process with restraint-oriented Russian tourists showed that the service recovery paradox did not take place with restraintoriented tourists [1]. This is primarily due to the fact that people from restraint cultures are more likely to remember negative experiences as opposed to positive ones [26]. It was also seen that tourists from restraint cultures were more influenced by the negative online reviews and they were more likely to avoid booking when they encountered negative comments [108].

Due to the fact that they have high expectations, customers from cultures with high power difference tend to evaluate the service processes and the overall service quality more negatively $[41,109,110]$. It was argued that Turkish tourists (high power distance) were less satisfied than tourists from the Netherlands, the UK, and Denmark (relatively low 
power distance cultures) who had their holidays in the same resort hotel [1]. However, though they may be more critical, tourism and hospitality customers from cultures with high power difference are less likely to complain [111]. This means that problems and failures experienced by customers from cultures with high power difference may be harder to identify as they do not express their dissatisfaction directly. Coupled with the above supply-side problems, especially in terms the using indirect messages by service staff when communicating service problems, failures, and crises to superiors [101], the identification and tackling of service failures and finding solutions can be problematic in an environment with a culture of high power distance [1].

It is interesting to see that the satisfaction with the service recovery process of tourism and hospitality customers from cultures with high power difference such as China, South Korea, and Japan increases when the apology in the service recovery process comes from a high-rank employee, i.e., a manager, rather than a lower-rank employee [112]. A research study that compared the Japanese (high power distance) and the US (low power distance) tourism and hospitality customers found that people from cultures with high power difference view themselves as being superior to the service providers, and, hence, they tend to view interaction attempts by the service providers as negatively [55]. On the other hand, customers from cultures with a low power distance do not tend to view interaction attempts by service providers negatively as they are more likely to ignore formalities in communicating with the service staff because they view themselves as being equal to them. Based on the above research findings, it may be proposed that in cultures with high power difference customer participation may be more problematic as customer participation may increase the number and intensity of interactions between the customers and service staff unless customer participation takes place through the use of technology [1].

Research shows that although tourism and hospitality customers from Hong Kong may not prefer to interact with the service providers due to their high power distance orientation, they may be keen to ask for dish recommendations from restaurant service providers due to their orientations toward high uncertainty avoidance [113]. Additionally, tourists from Hong and Kong, and Taiwan liked ordering food to share with friends [114]. However, while tourists from Hong Kong ordered more to try various food items at once, a risk-reducing strategy as they had a high level of uncertainty avoidance, Taiwanese tourists ordered food to share with friends for enjoying food together.

\subsection{Physical Evidence}

Physical evidence in tourism and hospitality may refer to a wide variety of aspects such as buildings, furniture, decoration, equipment, and the appearance of service personnel. Some explanations regarding the physical evidence were already made above under the product and promotion element. For instance, it was explained that the grandeur of tangible objects (buildings, amenities such as the rooms at a hotel or the swimming pool, furniture, etc.) had a more positive influence on people from cultures with high power difference as the grandeur of these objects meant higher status, luxury, exclusivity, and elitism for them [39].

Additionally, research shows that the tangible elements in tourism and hospitality were among the important criteria when customers from cultures with high power difference explained their purchase decisions, and later their service quality evaluations $[9,30,39]$. This is because the tangibles in the tourism and hospitality service satisfy the aspirations of customers from cultures with high power difference by enhancing credibility to belong to a superior social class and showing higher levels of prestige and wealth. [41]. Spas, extensive beaches, or rock-climbing facilities are more likely to be preferred by customers from cultures with high power difference as they signal exclusivity, elitism, and a higher status in the hierarchy [39]. In general, tourists from individualistic, long-term-oriented, indulgent, and strong uncertainty-avoiding cultures are more likely to place greater importance on the tangible aspects of the hotels during their stays [115]. For instance, a study [116] that compared Taiwanese (with a culture of high uncertainty avoidance) and US tourists (with a 
culture of low uncertainty avoidance) discovered that the tangible elements were relatively more influential for the Taiwanese when they made their service quality evaluations and purchase decisions. This was due to the fact that tourism and hospitality services posed various types of risks due to the intangibility characteristic, and the tangible cues helped risk aversive customers reduce their risk perceptions. Additionally, traditional cultural phenomena such as Feng Shui (the ancient Chinese art of balancing the flow of energy about the physical environment in buildings and amenities) were important in terms of service quality evaluations of customers from this region [117].

\section{Conclusions}

This study showed how intercultural differences may influence consumers, service providers, processes, and systems in tourism and hospitality in terms of the design and delivery of the marketing mix (7Ps) elements. The findings help clarify a deeper understanding of two major areas. Firstly, this study provides several examples for each of the cultural variables, enabling a deeper understanding of these cultural variables. Secondly, with several examples, from different countries and cultures, the study enables a deeper understanding of how cultural variables may influence the design and delivery of each of the marketing mix elements. The findings can be used by the practitioners in various sub-sectors of tourism and hospitality such as accommodation, transportation, food, and catering, etc. For instance, all major works in the field point out that people from cultures with high power difference place a greater significance on the physical/tangible elements. Hence, the practitioners catering to the customers mainly from cultures with high power difference need to make sure that physical/tangible elements of the business satisfy customers' aspirations for status, hierarchy, and elitism. It was also shown above that customers from masculine cultures tend to be more positive towards monetary-based sales promotions, while customers from feminine cultures are more likely to be positive towards non-monetary sales promotions. Hence, when targeting customers from different countries, different sales promotions may be used for each country.

The study is useful for the researchers as it provides a comprehensive and compact yet succinct framework for researchers intending to carry out research in tourism and hospitality. So far, studies have concentrated on one or a few cultural variables/dimensions, one or few countries, and one marketing mix element, or various sub-elements of the marketing mix. It may be argued that when one researcher studies one cultural variable, the influences of the other cultural characteristics cannot be easily eliminated. For instance, there may be two collectivistic countries, while one may be indulgence-oriented the other may be restraint-oriented. When carrying out research on the influence of collectivism on various marketing and management issues, these two countries may be treated equally in the study. However, with the understanding established in this study, researchers may expand their coverage of the variables, which, in turn, may shed more light on the influences of cultural variables on various issues relating to marketing and management.

As a final word of conclusion, it needs to be stated that cultural studies have been criticized by researchers mainly based on the view that culture is not stable as it changes through time [118-121]. However, Hofstede [122,123] put forward that culture is fairly stable over time and that the dimensions tend to have roots that go back many centuries.

An investigation of the country scores for the period between 1970 and 2010 demonstrated that although the absolute scores for countries showed some minimal changes over time, the relative country positions and the difference between the countries tended to remain stable over the period [26]. However, it needs to be noted that people's attitudes and behaviors may change over time, even without any changes taking place in the scores of countries concerned.

For example, although tourists from collectivistic cultures (e.g., in China) traditionally are more likely to make their holiday arrangements through travel agencies and intermediaries, their attitudes and behaviors may change when they encounter adverse consequences, such as dealing with dishonest travel agencies and intermediaries [87]. 
Additionally, as a final word of caution, the implications should not be interpreted in isolation, based on one cultural dimension, as countries have different cultural characteristics regarding other dimensions, different outcomes may emerge. For instance, while the collectivistic features of a country (e.g., China, South Korea, United Arab Emirates) may lead people to emphasize cooperation and harmony, a high power distance orientation in a country may result in the purchase of tourism and hospitality products enhancing social status and prestige [1].

Author Contributions: Conceptualization, E.K. and A.Y.A. methodology, E.K. and A.Y.A. resources, E.K. and A.Y.A. data curation, E.K. and A.Y.A. writing-original draft preparation, E.K. and A.Y.A. writing-review and editing, E.K. and A.Y.A. All authors have read and agreed to the published version of the manuscript.

Funding: This research received no external funding.

Institutional Review Board Statement: Ethical review and approval were waived for this study, as this is a review paper.

Informed Consent Statement: Not needed as this is a review paper.

Data Availability Statement: All data used in this study are included in the text.

Conflicts of Interest: The authors declare no conflict of interest.

\section{References}

1. Koc, E. Cross-Cultural Aspects of Tourism and Hospitality: A Services Marketing and Management Perspective; Routledge: London, UK, 2021.

2. Ward, C. Thinking outside the Berry boxes: New perspectives on identity, acculturation and intercultural relations. Int. J. Intercult Relat 2008, 32, 105-114. [CrossRef]

3. Wang, W.; Zhou, M. Validation of the short form of the intercultural sensitivity scale (ISS-15). Int. J. Intercult. Relat. 2016, 55, $1-7$. [CrossRef]

4. Neuliep, J.W. Intercultural Communication: A Contextual Approach, 7th ed.; Sage Publications: Thousand Oaks, CA, USA, 2018.

5. Yang, H.; Cheung, C.; Li, W. Intercultural Communication Competency Practices in the Hotel Industry. J. China Tour. Res. 2020, 1-23. [CrossRef]

6. Matusitz, J. Disneyland Paris: A case analysis demonstrating how glocalization works. J. Strateg. Mark 2010, 18, $223-237$. [CrossRef]

7. Fan, D.X.; Qiu, H.; Jenkins, C.L.; Lau, C. Towards a better tourist-host relationship: The role of social contact between tourists' perceived cultural distance and travel attitude. J. Sustain. Tour. 2021. [CrossRef]

8. Currie, R.R.; Gagnon, M. When do individuals become pleasure travellers? An exploratory study into the relationship between the fulfilment of primary expectations and the liminoid state. J. Travel Tour. Mark. 1999, 8, 115-128. [CrossRef]

9. Koc, E. Total quality management and business excellence in services: The implications of all-inclusive pricing system on internal and external customer satisfaction in the Turkish tourism market. Total. Qual. Manag. Bus. Excell. 2006, 17, 857-877. [CrossRef]

10. Koc, E. Intercultural Competence in Tourism and Hospitality: Self-Efficacy Beliefs and the Dunning Kruger Effect. Int. J. Intercult. Relat. 2021, 82, 175-184. [CrossRef]

11. Mihalič, T.; Fennell, D. In pursuit of a more just international tourism: The concept of trading tourism rights. J. Sustain. Tour. 2015, 23, 188-206. [CrossRef]

12. Peng, R.Z.; Wu, W.P. Measuring intercultural contact and its effects on intercultural competence: A structural equation modeling approach. Int. J. Intercult. Relat. 2016, 53, 16-27. [CrossRef]

13. Lieberman, D.A.; Gamst, G. Intercultural communication competence revisited: Linking the intercultural and multicultural fields. Int. J. Intercult. Relat. 2015, 48, 17-19. [CrossRef]

14. Koc, E. Service Failures and Recovery in Tourism and Hospitality: A Practical Manual; CABI: Oxford, UK, 2017.

15. Koc, E. Service failures and recovery in hospitality and tourism: A review of literature and recommendations for future research. J. Hosp. Mark. Manag. 2019, 28, 513-537. [CrossRef]

16. Kumar, S.; Dhir, A. Associations between travel and tourism competitiveness and culture. J. Dest. Mark. Manag. 2021, 18, 100501.

17. Buckley, R.C.; Cooper, M.A. Assortative matching of tourists and destinations: Agents or algorithms? Sustainability 2021, 13, 1987. [CrossRef]

18. Cooper, M.-A.; Camprubí, R.; Koc, E.; Buckley, R. Digital Destination Matching: Practices, Priorities, \& Predictions. Sustainability 2021, in press.

19. Lim, S.E.; Ok, C.M. A meta-analytic review of antecedents of hospitality and tourism firms' performance: A cross-cultural comparison. Tour. Manag. 2021, 86, 104325. [CrossRef] 
20. World Travel and Tourism Council. Tourism Impact. 2020. Available online: https://www.wttc.org/economic-impact/countryanalysis/ (accessed on 22 September 2021).

21. United Nations World Tourism Organisation. International Tourism Growth Continues to Outplace the Global Economy. 2020. Available online: https:/ / unwto.org/international-tourism-growth-continues-to-outpace-the-economy (accessed on 22 September 2021).

22. World Travel \& Tourism Council. Economic Impact 2019: World; World Travel and Tourism Council: London, UK, 2019.

23. Koc, E. Power distance and its implications for upward communication and empowerment: Crisis management and recovery in hospitality services. Int. J. Hum. Resour. Manag. 2013, 24, 3681-3696. [CrossRef]

24. Kwok, S.; Uncles, M. Sales promotion effectiveness: The impact of consumer differences at an ethnic-group level. J. Prod. Brand. Manag. 2005, 14, 170-186. [CrossRef]

25. Hall, E.T. Beyond Culture; Anchor Press: Garden City, NY, USA, 1977.

26. Hofstede, G.; Hofstede, G.J.; Minkov, M. Cultures and Organizations: Software of the Mind, 3rd ed.; McGraw-Hill: New York, NY, USA, 2010.

27. Cardon, P.W. A critique of Hall's contexting model: A meta-analysis of literature on intercultural business and technical communication. J. Bus. Tech. Commun. 2008, 22, 399-428. [CrossRef]

28. Kyoung-Ah, N.; Cho, Y.; Lee, M. West meets East? Identifying the gap in current cross-cultural training research. Hum. Resour. Dev. 2014, 13, 36-57.

29. Ferreira, M.P.; Li, D.; Reis, N.R.; Serra, F.R. Culture in international business research. Management Research. J. Iber. Acad. Manag. 2014, 12, 68-91.

30. Litvin, S.W.; Crotts, J.C.; Hefner, F.L. Cross-cultural tourist behaviour: A replication and extension involving Hofstede's uncertainty avoidance dimension. Int. J. Tour. Res. 2004, 6, 29-37. [CrossRef]

31. Litvin, S.W.; Kar, G.H. Individualism/collectivism as a moderating factor to the self-image congruity concept. J. Vacat. Market. 2003, 10, 23-42. [CrossRef]

32. Crotts, J.C.; Erdmann, R. Does national culture influence consumers' evaluation of travel services? A test of Hofstede's model of cross-cultural differences. Manag. Serv. Qual. 2000, 10, 410-419. [CrossRef]

33. Connell, J. Contemporary medical tourism: Conceptualisation, culture and commodification. Tour. Manag. 2013, 34, 1-13. [CrossRef]

34. Su, N.; Min, H.; Chen, M.H.; Swanger, N. Cultural CharaCteristics and tourist shopping spending. J. Hosp. Tour. 2018, 42, 1210-1231. [CrossRef]

35. Ozdemir, C.; Yolal, M. Cross-cultural tourist behavior: An examination of tourists' behavior in guided tours. Tour. Hosp. Res. 2017, 17, 314-324. [CrossRef]

36. Timothy, D.J.; Butler, R.W. Cross-border shopping: A North American perspective. Ann. Tour. Res. 1995, 22, 16-34. [CrossRef]

37. Reisinger, Y. Cross-cultural differences in tourist behaviour. In Handbook of Tourist Behaviour: Theory E Practice; Kozak, M., Decrop, A., Eds.; Routledge: New York, NY, USA, 2009; pp. 237-255.

38. Park, S.Y. A comparison of Korean and American gift-giving behaviours. Psychol. Mark. 1998, 15, 577-593. [CrossRef]

39. Correia, A.; Kozak, M.; Ferradeira, J. Impact of culture on tourist decision-making styles. Int. J. Tour. 2011, 13, 433-446. [CrossRef]

40. Furrer, O.; Liu, B.S.C.; Sudharshan, D. The relationships between culture and service quality perceptions: Basis for cross-cultural market segmentation and resource allocation. J. Serv. Res. 2000, 2, 355-371. [CrossRef]

41. Nath, P.; Devlin, J.; Reid, V. Expectation formation in case of newer hotels: The role of advertising, price, and culture. J. Travel Res. 2016, 55, 261-275. [CrossRef]

42. Becker, C. Service recovery strategies: The impact of cultural differences. J. Hosp. Tour. 2000, 24, 526-538. [CrossRef]

43. Harris, P.; Rettie, R.; Cheung, C.K. Adoption and usage of m-commerce: A cross-cultural comparison of Hong Kong and the United Kingdom. J. Electron. Commer. Res. 2005, 6, 210-224.

44. Koc, E. Inversionary and liminoidal consumption: Gluttony on holidays and obesity. J. Travel Tour. Mark. 2013, 30, 825-838. [CrossRef]

45. Reisinger, Y.; Mavondo, F. Cultural differences in travel risk perception. J. Travel Tour. Mark. 2006, 20, 13-31. [CrossRef]

46. Gray, J.M.; Wilson, M. The relative risk perception of travel hazards. Environ. Behav. 2009, 41, 185-204. [CrossRef]

47. Williams, A.M.; Baláž, V. Tourism, risk tolerance and competences: Travel organization and tourism hazards. Tour. Manag. 2021, 35, 209-221. [CrossRef]

48. Chen, Y.; Jiang, K. A multiple indicators multiple causes (mimic) model of the behavioral consequences of hotel guests. Tour. Manag. Persp. 2019, 30, 197-207. [CrossRef]

49. Ahmed, Z.U.; Krohn, F.B. Understanding the unique consumer behavior of Japanese tourists. J. Travel Tour. Mark. 1993, 1, 73-86. [CrossRef]

50. Money, B.; Crotts, J.C. The Effect of Uncertainty Avoidance on Information Search, Planning and Purchases of International Travel Vacations. Tour. Manag. 2003, 24, 191-202. [CrossRef]

51. Reisinger, Y.; Crotts, J.C. Applying Hofstede's national culture measures in tourism research: Illuminating issues of divergence and convergence. J. Travel Res. 2010, 49, 153-164. [CrossRef] 
52. Manrai, L.A.; Manrai, A. Hofstede's cultural dimensions and tourist behaviors: A review and conceptual framework. J. Econ. Financ. Adm. Sci. 2011, 16, 23-48.

53. Han, B.; Heather, J. Korean Tourists' Characteristics in Guam. J. Georg 2001, 11, 69-83.

54. Stauss, B.; Mang, P. Culture shocks in inter-cultural service encounters. J. Serv. Mark. 1999, 13, 329-346. [CrossRef]

55. Lee, H.E. Does a server's attentiveness matter? Understanding intercultural service encounters in restaurants. Int. J. Hosp. Manag. 2015, 50, 134-144. [CrossRef]

56. Bergadaa, M. The role of time in the action of the consumer. J. Consum. Res. 1990, 17, 289-302. [CrossRef]

57. Cotte, J.; Ratneshwar, S. Timestyle and leisure decisions. J. Leis. Res. 2001, 33, 396-409. [CrossRef]

58. Li, M.; Cai, L.A. The effects of personal values on travel motivation and behavioral intention. J. Travel Res. 2012, 51, 473-487. [CrossRef]

59. Lu, J.; Hung, K.; Wang, L.; Schuett, M.A.; Hu, L. Do perceptions of time affect outbound-travel motivations and intention? An investigation among Chinese seniors. Tour. Manag. 2016, 53, 1-12. [CrossRef]

60. Ahn, Y.J.; Janke, M.C. Motivations and benefits of the travel experiences of older adults. Educ. Gerontol. 2011, 37, 653-673. [CrossRef]

61. Miao, L.; Lehto, X.; Wei, W. The hedonic experience of travel-related consumption. In International CHRIE Conference-Referred Track. Paper 7. 2011. Available online: http:/ / scholarworks.umass.edu/refereed/ICHRIE_2011/Saturday/7 (accessed on 23 September 2021).

62. Pizam, A.; Fleischer, A. The relationship between cultural characteristics and preference for active vs. passive tourist activities. J. Hosp. Leis. Market. 2005, 12, 5-25. [CrossRef]

63. Bhattacharyya, K.; Borhart, A. National Cultural Values on Service Quality: A Typology for Global Dining Experience in the 21 st Century. J. Serv. Sci. Res. 2018, 10, 1-24. [CrossRef]

64. Jeong, J.Y.; Crompton, J.L.; Hyun, S.S. What makes you select a higher price option? Price-quality heuristics, cultures, and travel group compositions. Int. J. Tour. 2019, 21, 1-10. [CrossRef]

65. Lalwani, A.K.; Forcum, L. Does a dollar get you a dollar's worth of merchandise? The impact of power distance belief on price-quality judgments. J. Consum. Res. 2016, 43, 317-333. [CrossRef]

66. Mattila, A.S.; Choi, S. A cross-cultural comparison of perceived fairness and satisfaction in the context of hotel room pricing. Int. J. Hosp. Manag. 2006, 25, 146-153. [CrossRef]

67. Sabiote-Ortiz, C.M.; Frías-Jamilena, D.M.; Castañeda-García, J.A. Overall perceived value of a tourism service delivered via different media: A cross-cultural perspective. J. Travel Res. 2016, 55, 34-51. [CrossRef]

68. Kwak, H.; Zinkhan, G.M.; Roushanzamir, E.P.L. Compulsive comorbidity and its psychological antecedents: A cross cultural comparison between The US and South Korea. J. Consum. Mark. 2004, 21, 418-434. [CrossRef]

69. Park, S.B.; Chung, N.; Woo, S.C. Do reward programs build loyalty to restaurants? The moderating effect of long-term orientation on the timing and types of rewards. Manag. Serv. Qual. 2013, 23, 225-244. [CrossRef]

70. Gu, G.; Ryan, C. Chinese Clientele at Chinese Hotels-preferences and Satisfaction. Int. J. Hosp. Manag. 2008, 27, 337-345. [CrossRef]

71. Au, N.; Law, R.; Buhalis, D. The impact of culture on eComplaints: Evidence from Chinese consumers in hospitality organisations. In ENTER 2010 Proceedings; Gretzel, U., Law, R., Fuchs, M., Eds.; Springer: Vienna, NY, USA, 2010; pp. 285-296.

72. Frías, D.M.; Rodríguez, M.A.; Alberto Castañeda, J.; Sabiote, C.M.; Buhalis, D. The formation of a tourist destination's image via information sources: The moderating effect of culture. Int. J. Tour. Res. 2012, 14, 437-450. [CrossRef]

73. Lim, K.H.; Leung, K.; Sia, C.L.; Lee, M.K.O. Is e-commerce boundary-less? Effects of individualism-collectivism and uncertainty avoidance on internet shopping. J. Int. Bus. Stud. 2004, 35, 545-559. [CrossRef]

74. Suki, N.; Suki, N. Online buying innovativeness: Effects of perceived value, perceived risk and perceived enjoyment. Int. J. Bus. Soc. 2007, 8, 81-93.

75. Huang, S.S.; Chen, G. Current state of tourism research in China. Tour. Manag. Persp. 2016, 20, 10-18. [CrossRef]

76. Chen, J.S.; Gursoy, D. Cross-Cultural Comparison of the Information Sources by First-Time and Repeat Travelers and Its Marketing Implications. Int. J. Hosp. Manag. 2000, 19, 191-203. [CrossRef]

77. Würtz, E. Intercultural communication on web sites: A cross-cultural analysis of web sites from high-context cultures and low-context cultures. J. Comput.-Mediat. Commun. 2005, 112, 74-299. [CrossRef]

78. Bai, H. A cross-cultural analysis of advertisements from high-context cultures and low-context cultures. Eng. Lang. 2016, 9, 21-27. [CrossRef]

79. Le Pair, R.; Van Mulken, M. Perceived Complexity and Appreciation of Visual Metaphors by Consumers with Different Cultural Backgrounds. In New Trends in Advertising Research; Costa Pereira, F., Veríssimo, J., Neijens, P., Eds.; Sílabo: Lisbon, Portugal, 2008; pp. 279-290.

80. Hornikx, J.; le Pair, R. The influence of high-/low-context culture on perceived Ad complexity and liking. J. Glob. Mark. 2017, 30, 228-237. [CrossRef]

81. Callow, M.; Schiffman, L. Implicit meaning in visual print advertisements: A cross-cultural examination of the contextual communication effect. Int. J. Advert. 2002, 21, 259-277. [CrossRef]

82. Pollay, R.W.; Gallagher, K. Advertising and cultural values: Reflections in the distorted mirror. Int. J. Advert. 1990, 9, 359-372. [CrossRef] 
83. Albers-Miller, N.D.; Gelb, B.D. Business advertising appeals as a mirror of cultural dimensions: A study of eleven countries. J. Advert. 1996, 25, 57-70. [CrossRef]

84. Cheong, Y.; Kim, K.; Zheng, L. Advertising appeals as a reflection of culture: A cross-cultural analysis of food advertising appeals in China and the US. Asian J. Cummun. 2010, 20, 1-16. [CrossRef]

85. Swaminathan, F. The Uncommon Sense of Advertising-Understanding Contemporary Advertising Appeals in Press of Top Advertisers in India. In Proceedings of the LCBR European Marketing Conference, Munich, Germany, 9-10 August 2012.

86. Parker, B.J. Food for health: The use of nutrient content, health, and structure/function claims in food advertisement. J. Advert. 2003, 32, 47-55. [CrossRef]

87. Hsu, C.H.; Huang, S.S. Reconfiguring Chinese cultural values and their tourism implications. Tour. Manag. 2016, 58, 230-242. [CrossRef]

88. Diehl, S.; Terlutter, R.; Mueller, B. Doing good matters to consumers: The effectiveness of humane-oriented CSR appeals in cross-cultural standardized advertising campaigns Int. J. Advert. 2016, 35, 730-757. [CrossRef]

89. Rojas-Me'ndez, J.I.; Davies, G.; Omer, O.; Chetthamrongchai, P.; Madra, C. A time attitude scale for cross-cultural research. J. Glob. Mark. 2017, 15, 117-147. [CrossRef]

90. Mattila, A. Culture in evaluating services. J. Serv. Res. 1999, 1, 250-261. [CrossRef]

91. Koc, E.; Ayyildiz, Y.A. An overview of tourism and hospitality scales: Discussion and recommendations. J. Hosp. Tour. Insights 2021, in press. [CrossRef]

92. De Mooij, M. Consumer Behavior and Culture: Consequences for Global Marketing and Advertising; Sage: Newcastle upon Tyne, UK, 2010.

93. Humphrey, C. To Smile and Not to Smile: Mythic Gesture at the Russia-China Border. Soc. Anal. 2018, 62, 31-54. [CrossRef]

94. Hamid, M.A. Does Culture Impact Choice of Pictures for Websites: An Analysis of Chinese Cultural Dimensions on Websites of Chinese Universities. New Media Mass Commun. 2016, 45, 34-45.

95. Zhao, D. The Effects of Culture on International Advertising Appeals: A Cross-Cultural Content Analysis of US and Japanese Global Brands. Prof. Proj. Coll. J. Mass Commun. 2017, 15, 13-14.

96. Huang, Z.; Huang, S.; Yang, Y.; Tang, Z.; Yang, Y.; Zhou, Y. In pursuit of happiness: Impact of the happiness level of a destination country on Chinese tourists' outbound travel choices. Int. J. Tour. 2020, 23, 713-725. [CrossRef]

97. Nelson, M.R.; Paek, H.J. Cross-cultural differences in sexual advertising content in a transnational women's magazine. Sex Roles 2005, 53, 371-383. [CrossRef]

98. Seo, S.; Kim, K.; Jang, J. Uncertainty avoidance as a moderator for influences on foreign resident dining out behaviors. Int. J. Contemp. Hosp. Manag. 2018, 30, 900-918. [CrossRef]

99. McNeill, L. The influence of culture on retail sales promotion use in Chinese supermarkets. Australas. Mark. J. 2006, 14, 34-46. [CrossRef]

100. McNeill, L.S.; Fam, K.S.; Chung, K. Applying transaction utility theory to sales promotion-the impact of culture on consumer satisfaction. Int. Rev. Retail. Distrib. Consum. Res. 2014, 24, 166-185. [CrossRef]

101. Kang, K.H.; Lee, S.; Yoo, C. The effect of national culture on corporate social responsibility in the hospitality and tourism industry. Int. J. Contemp. Hosp. Manag. 2016, 28, 1728-1758. [CrossRef]

102. Filimonau, V.; Matute, J.; Mika, M.; Faracik, R. National culture as a driver of pro-environmental attitudes and behavioural intentions in tourism. J. Sust. Tour. 2018, 26, 1804-1825. [CrossRef]

103. Zheng, T.M.; Zhu, D.; Kim, P.B.; Williamson, D. An Examination of the Interaction Effects of Hospitality Employees' Motivational and Cultural Factors in the Workplace. J. Sustain. Tour. 2018, in press. [CrossRef]

104. Magnini, V.P.; Hyun, S.; Kim, B.; Uysal, M. The influences of collectivism in hospitality work settings. Int. J. Contemp. Hosp. Manag. 2013, 25, 844-864. [CrossRef]

105. Jia, S.S. Motivation and satisfaction of Chinese and US tourists in restaurants: A cross-cultural text mining of online reviews. Tour. Manag. 2020, 78, 104071. [CrossRef]

106. Nedeljković, M.; Hadžić, O.; Čerović, S. Organizational changes and job satisfaction in the hospitality industry in Serbia. UTMS J. Econ. 2012, 3, 105-117.

107. Doyle, P. Value-Based Marketing. Marketing Strategies for Corporate Growth and Shareholder Value, 2nd ed.; John Wiley \& Sons: West Sussex, UK, 2010.

108. Ruiz-Equihua, D.; Romero, J.; Casaló, L.V. Better the devil you know? The moderating role of brand familiarity and indulgence vs. restraint cultural dimension on eWOM influence in the hospitality industry. J. Hosp. Mark. Manag. 2020, 29, 310-328. [CrossRef]

109. Ladhari, R.; Pons, F.; Bressolles, G.; Zins, M. Culture and personal values: How they influence perceived service quality. J. Bus. Res. 2011, 64, 951-957. [CrossRef]

110. Gao, B.; Li, X.; Liu, S.; Fang, D. How power distance affects online hotel ratings: The positive moderating roles of hotel chain and reviewers' travel experience. Tour. Manag. 2018, 65, 176-186. [CrossRef]

111. Yuksel, A.; Kilinc, U.K.; Yuksel, F. Cross-national analysis of hotel customers' attitudes toward complaining and their complaining behaviors, Tour. Manag. 2006, 1, 11-24.

112. Patterson, P.F.; Cowley, E.; Prasongsukarn, K. Service Failure Recovery: The Moderating Impact of Individual-Level Cultural Value Orientation on Perceptions of Justice. Int. J. Res. Mark. 2006, 23, 263-277. [CrossRef] 
113. Chang, R.C.Y.; Kivela, J.; Mak, A.H.N. Food preferences of Chinese tourists. Ann. Tour. Res. 2010, 37, 989-1011. [CrossRef]

114. Wan, Y.K.P.; Kim, S.S. Intracultural differences in dining behavior and preferences among Hong Kong and Taiwan tourists. Int. J. Cult. Tour. 2021, in press.

115. Zhang, P.; Gerdes, J.H., Jr. The impact of national culture on hotel guest evaluation-A big data approach. Int. J. Tour. 2020, 22, 582-592. [CrossRef]

116. Hsieh, A.T.; Tsai, C.W. Does national culture really matter? Hotel service perceptions by Taiwan and American tourists. Int. J. Cult. Tour. 2009, 3, 54-69. [CrossRef]

117. Huang, L.S.; Teng, C.I. Development of a Chinese superstitious belief scale. Psychol. Rep. 2009, 104, 807-819. [CrossRef]

118. McSweeney, B. Hofstede's model of national cultural differences and their consequences: A triumph of faith-a failure of analysis. Hum. Relat. 2002, 55, 89-117. [CrossRef]

119. Sweeney, B. The essentials of scholarship: A reply to Hofsted. Hum. Relat. 2009, 55, 1363-1372.

120. Luigi, G.; Paola, S.; Luigi, Z. Does Culture Affect Economic Outcomes? J. Econ. Perspect. 2006, $20,23-48$.

121. Ailon, G. Mirror, mirror on the wall: Culture's Consequences in a value test of its own design. Acad. Manag. Rev. 2008, 33, 885-904. [CrossRef]

122. Hofstede, G. Dimensions do not exist: A reply to Brendan McSweeney. Hum. Relat. 2002, 55, 1355-1361. [CrossRef]

123. Hofstede, G. Who is the fairest of them all? Galit Ailon's mirror. Acad. Manag. Rev. 2009, 34, 570-571. [CrossRef] 